\title{
Ap 1,7 - "Idoú érchetai metá tôn nephelôn" O oráculo apocalíptico do advento de Jesus Cristo no escopo introdutório do Apocalipse joanino
}

\author{
Orientador: Geraldo Dondici Vieira
}

Mestrando: Vitor de Oliveira Abreu

Área de Concentração: Teologia Bíblica

Linha de Pesquisa: Análise e Interpretação de Textos do Antigo e Novo Testamento

O Apocalipse oferece aos seus leitores uma densa cristologia desde o início do livro e propõe a certeza da realidade transcendente através de um oráculo que evoca e celebra a vinda da supremacia divina a partir da experiência histórica e trans-histórica do próprio Cristo, a fim de proporcionar encorajamento e esperança às comunidades do cristianismo originário que atravessavam seus próprios desafios.

Palavras-chave: Vinda, Supremacia Divina, Literatura Apocalíptica. 